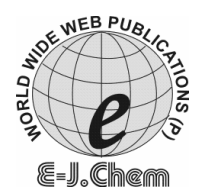

ISSN: 0973-4945; CODEN ECJHAO

http://www.e-journals.net

\title{
Uptake of Cationic Dyes from Aqueous Solution by Biosorption Using Granulized Annona squmosa Seed
}

\author{
T. SANTHI* and S. MANONMANI \\ *Department of Chemistry, Karpagam University, \\ Coimbatore-641021, India \\ Department of Chemistry, PSG College of Arts and Science, \\ Coimbatore-641014, India. \\ ssnilasri@yahoo.co.in
}

Received 25 January 2009; Accepted 18 March 2009

\begin{abstract}
A new, low cost, locally available biomaterial was tested for its ability to remove cationic dyes from aqueous solution. A sample of granulized Annona squmosa seeds had been utilized as a sorbent for uptake of three cationic dyes, methylene blue (MB), methylene red (MR) and malachite green (MG). The effects of various experimental parameters (e.g., contact time, dye concentration, adsorbent dose and $\mathrm{pH}$ ) were investigated and optimal experimental conditions were ascertained. Above the value of initial $\mathrm{pH} 5$, three dyes studied could be removed effectively. The isothermal data fitted the Langmuir model in the case of MB sorption and the Freundlich model for all three dyes sorption. The biosorption processes followed the pseudo first order rate kinetics. The results in this study indicated that granulized Annona squmosa seed was an attractive candidate for removing cationic dyes from the dye wastewater.
\end{abstract}

Keywords: Annona squmosa, Biosorption, Methylene blue, Methylene red, Malachite green.

\section{Introduction}

Contamination of the environment from a variety of sources has become an increasingly serious problem in recent years. The release of dyes into wastewaters by various industries poses serious environmental problems due the persistent and recalcitrant nature of the dyes. The presence of dyes in waterways is easily detectable even in small concentrations. The coloration of the water by the dyes may have an inhibitory effect on photosynthesis affecting aquatic ecosystems. Dyes may also be problematic if they are broken down an aerobically in 
the sediment, as toxic amines are often produced due to incomplete degradation by bacteria. Some of the dyes or their metabolites are either toxic or mutagenic and carcinogenic ${ }^{1}$.

Synthetic dyes have complex aromatic structures, which provide them physiochemical, thermal, biological and optical stability. The USEPA (Environmental Protection Agency) has classified textile wastes into four groups; dispersible, hard-to-treat, high volume, hazardous and toxic wastes ${ }^{2}$. Basic dyes are the brightest class of soluble dyes used by the textile industry. The dye causes irritation to the gastrointestinal tract with symptoms of nausea, vomiting, and diarrhea. It may also cause methemoglobinemia, convulsions, and dyspnea, if inhaled. It is likely to cause irritation to the $\mathrm{skin}^{3}$. Hence, it is necessary to remove dyes from wastewater.

Many methods are available for the removal of dyes from waters. Among these methods, adsorption is by far the most versatile and widely used method because of its low cost, ease of operation. A number of agricultural waste and by-products of cellulose origin have been studied for their capacity to remove dyes from aqueous solutions, such as peanut hulls ${ }^{4}$, maize bran ${ }^{5}$, sawdust ${ }^{6}$, sugar beet pulp ${ }^{7}$, crab shell $^{8}$, cornstarch $^{9}$, rice husk ${ }^{10}$, chitin $^{11}$, orange waste $^{12}$, lemon peel ${ }^{13}$, granular kohlrabi peel ${ }^{14}$,raw barley straw ${ }^{15}$, sago waste ${ }^{16}$.

Therefore, there is the need to look for low cost alternatives in easily available biomaterials, which can adsorb dyes from wastewaters. In this paper, we attempt to use an agricultural by-product, granulized Annona squmosa seed, as adsorbent for the removal of dyes from water. These sorbents can be used once, and then disposed as fuel for power generation or as a fermentation substrate to produce fertilizer for vegetable cultivation.

\section{Experimental}

\section{Preparation of the Annona squmosa sorbent}

The Annona squmosa was obtained from an agricultural farm in Coimbatore District (Tamil $\mathrm{Nadu}$ ). The seed of Annona squmosa was washed thoroughly with distilled water then dried in an oven at $100{ }^{\circ} \mathrm{C}$ to a constant weight. Dry biomass was crushed into granules, sieved to different particle sizes and then preserved in a desiccator for use.

\section{Preparation of cationic dye solutions}

Three cationic dyes (MB, MR and MG) in commercial purity were obtained from Fluka and used without further purification. The dye stock solutions were prepared by dissolving accurately weighted dyes in distilled water to the concentration of $500 \mathrm{mg} / \mathrm{L}$. The experimental solutions were obtained by diluting the dye stock solutions in accurate proportions to different initial concentrations.

\section{Experimental methods and measurements}

Biosorption experiments were carried out in a rotary shaker at $150 \mathrm{rpm}$ using $250 \mathrm{~mL}$ shaking flasks containing $50 \mathrm{~mL}$ of dye solutions at different concentrations and initial $\mathrm{pH}$ values of dye solutions. The initial $\mathrm{pH}$ values of the solutions were previous adjusted with $0.1 \mathrm{M} \mathrm{HCl}$ or $\mathrm{NaOH}$ using a DEEP VERSION model (EI) $\mathrm{pH}$ meter. The adsorbent $(0.2 \mathrm{~g})$ was added to each flask, and then the flasks were sealed up to prevent any change of volume of the solution during the experiments. After shaking the flasks for a predetermined time intervals, the samples were withdrawn from the flasks and the dye solutions were separated from the sorbent by filtration after centrifugation. The $\mathrm{pH}$ values of the separated dye solutions were again measured for examining their change. Dye concentrations in the supernatant solutions were estimated by measuring absorbance at maximum wavelengths of dye with a Systronic Spectrophotometer-104. The amounts of dyes sorbed by the biomass were calculated using the following equation: 


$$
\mathrm{q}=\left(\mathrm{C}_{0}-\mathrm{C}_{\mathrm{e}}\right) \mathrm{V} / \mathrm{W}
$$

where, $\mathrm{q}(\mathrm{mg} / \mathrm{g})$ is the amount of dye sorbed by the biomass, $\mathrm{C}_{0}$ and $\mathrm{Ce}(\mathrm{mg} / \mathrm{L})$ are the initial and equilibrium liquid phase concentration of dye respectively, $\mathrm{V}(\mathrm{L})$ the initial volume of dye solution and $\mathrm{W}(\mathrm{g})$ the weight of the biomass.

The effect of each parameter was studied by fixing the values of other parameters. The experiments were conducted with duplicate and the negative controls (with no sorbent) to ensure that sorption was by the granulized Annona squmosa seed biomass and not by the container.

\section{Results and Discussion}

\section{Influence of initial $\mathrm{pH}$}

The effect of initial $\mathrm{pH}$ on biosorption percentage of dyes was examined over a range of $\mathrm{pH}$ values from 2 to 10 and the results are presented in Figure 1. As elucidated in Figure 1, for all three dyes, the dye removal was minimum at the initial $\mathrm{pH} 2$. The dyes sorbed increased as the $\mathrm{pH}$ was increased from $\mathrm{pH} 2$ to 6 for $\mathrm{MB}$ and $\mathrm{pH} 2$ to 5 for both MR and MG, then, the dye removal decreased beyond $\mathrm{pH} 6$ for $\mathrm{MB}$ and 5 for both MR and MG respectively. For this reason, $\mathrm{pH} 6$ for $\mathrm{MB}$ and 5 for both $\mathrm{MR}$ and $\mathrm{MG}$ was selected for future experiments.

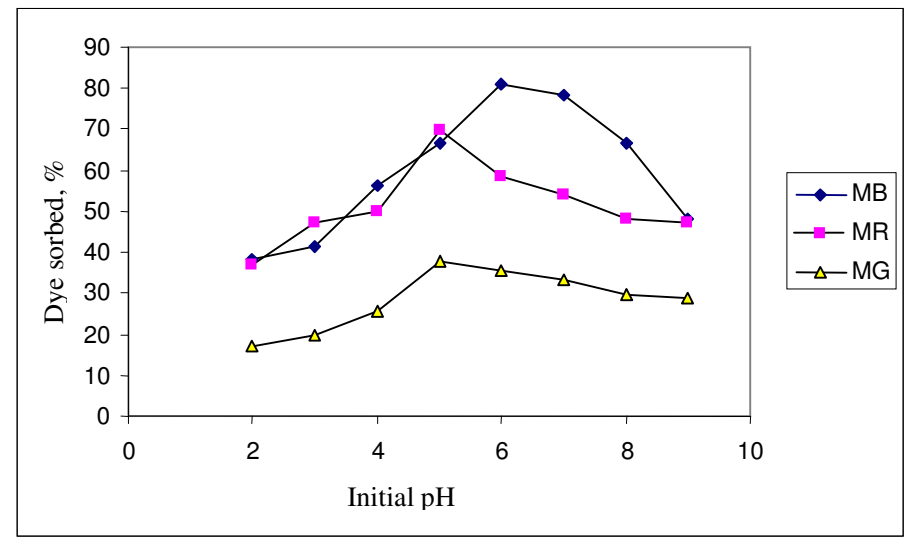

Figure 1. Influence of initial $\mathrm{pH}$ on biosorption of MB, MR and MG by granulized Annona squmosa seed. (Sorbent dose: $200 \mathrm{mg} / 50 \mathrm{~mL}$; particle size: 125-250 mu; contact time: $3 \mathrm{~h}$; dye concentration: $100 \mathrm{mg} / \mathrm{L}$ ).

After adsorption experiments, it was found that at low $\mathrm{pH}$ and at high $\mathrm{pH}$, the dye become protonated, the electrostatic repulsion between the protonated dyes and positively charged adsorbent sites results in decreased adsorption. Higher adsorption at pH 6 and 5 may be due to increased protonation by the neutralization of the negative charges at the surface of the adsorbent; which facilitates the diffusion process and provides more active sites for the adsorbent.

\section{Influence of initial dye concentration}

The influence of dye concentration on bioadsorption of dyes is shown in Figure 2, when the dye concentration was increased from 25 to $200 \mathrm{mg} / \mathrm{L}$, the percentage of dye adsorbed was between $55.56 \%$ and $98.36 \%(\mathrm{MB}), 50.00 \%$ and $87.21 \%(\mathrm{MR}), 13.69 \%$ and $56.087 \%(\mathrm{MG})$. With the data in Figure 2, the Langmuir and Freundlich equation were employed to study the adsorption isotherms of dyes.

The linearised form of the Langmuir equation is as follows

$$
\mathrm{C}_{\mathrm{e}} / \mathrm{q}_{\mathrm{e}}=1 /\left(\mathrm{a} \mathrm{Q}_{\mathrm{m}}\right)+\mathrm{C}_{\mathrm{e}} / \mathrm{Q}_{\mathrm{m}}
$$

where, $\mathrm{C}_{\mathrm{e}}(\mathrm{mg} / \mathrm{L})$ is the concentration of the dye solution at equilibrium, $\mathrm{q}_{\mathrm{e}}(\mathrm{mg} / \mathrm{g})$ is the 
amount of dye sorbed at equilibrium, $\mathrm{Q}_{\mathrm{m}}$ is the maximum adsorption capacity and represents a practical limiting adsorption capacity when the adsorbent surface is fully covered with monolayer adsorbent molecule and $\mathbf{a}$ is Langmuir constant. The $\mathrm{Q}_{\mathrm{m}}$ and a values are calculated from the slopes $\left(1 / \mathrm{Q}_{\mathrm{m}}\right)$ and intercepts $\left(1 / \mathbf{a} \mathrm{Q}_{\mathrm{m}}\right)$ of linear plots of $\mathrm{C}_{\mathrm{e}} / \mathrm{q}_{\mathrm{e}}$ versus $\mathrm{C}_{\mathrm{e}}$.

The linear form of the Freundlich equation is as follows:

$$
\ln \mathrm{Q}_{\mathrm{e}}=\ln \mathrm{K}+(1 / \mathrm{n}) \ln \mathrm{C}_{\mathrm{e}}
$$

where, $\mathrm{Q}_{\mathrm{e}}$ is the amount of dye adsorbed at equilibrium, $\mathrm{C}_{\mathrm{e}}$ is the concentration of the dye solution at equilibrium and $1 / \mathrm{n}$ are empirical constant and indicate adsorption capacity and intensity, respectively. Their values were obtained from the intercepts $(\ln K)$ and slope $(1 / n)$ of linear plots of $\ln \mathrm{Q}_{\mathrm{e}}$ versus $\ln \mathrm{C}_{\mathrm{e}}$

The $\mathrm{Q}_{\mathrm{m}}$ and $\mathbf{a}$ values in the Langmuir equation, the $\mathrm{k}$ and $1 / \mathrm{n}$ values in the Freundlich equation, the correlation coefficients of two equations are given in the Table 1 . The maximum sorption capacity $\left(\mathrm{Q}_{\mathrm{m}}\right)$ was $416.67 \mathrm{mg}$ dye per gram of the biosorbent for MB. From the results in Table 1, it could be concluded that the isothermal data fitted the Langmuir model in the case of MB sorption and the Freundlich model for all three dyes sorption.

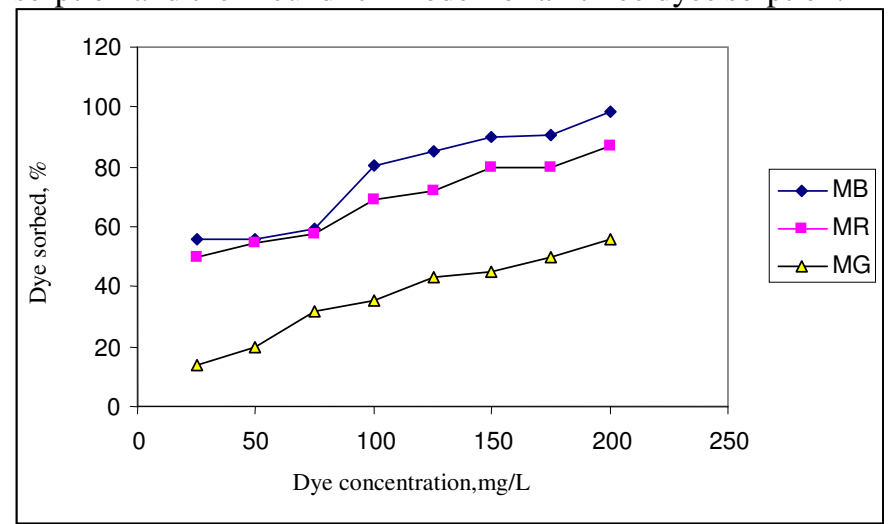

Figure 2. Influence of dye concentration on biosorption of MB, MR, and MG by granulized Annona squmosa seed (Sorbent dose: $200 \mathrm{mg} / 50 \mathrm{~mL}$; particle size: $125-250 \mathrm{m \mu}$; contact time: $3 \mathrm{~h}$; dye concentration: $100 \mathrm{mg} / \mathrm{L} ; \mathrm{pH}$ : 6.0 for $M B, 5$ for $M R \& M G)$.

Table 1. The $\mathrm{Q}_{\mathrm{m}}$, a values in the Langmuir equation, the $\mathrm{K}$ and $1 / \mathrm{n}$ values in Freundlich equation, the correlation coefficients of equations.

\begin{tabular}{|c|c|c|c|c|c|c|}
\hline & \multicolumn{3}{|c|}{ Langmuir } & \multicolumn{3}{|c|}{ Freundlich } \\
\hline & $\mathrm{Q}_{\mathrm{m}}(\mathrm{mg} / \mathrm{g})$ & $\mathbf{a}$ & $\mathrm{R}^{2}$ & $\mathrm{~K}$ & $1 / \mathrm{n}$ & $\mathrm{R}^{2}$ \\
\hline MB & 416.67 & 0.0001 & 0.0233 & 0.5355 & 0.9338 & 0.826 \\
\hline MR & - & - & 0.4748 & 0.0199 & 2.0246 & 0.6018 \\
\hline MG & - & - & 0.087 & 0.0019 & 2.2253 & 0.9565 \\
\hline
\end{tabular}

Effect of sorbent particle size

The effect of sorbent particle size on biosorption of dyes is shown in Figure 3. The dyes adsorbed increased as the sorbent particle size decreased. It was suggested that the increase in sorption depended on the large external surface area for small particles; this removes more dye in the initial stages of the sorption process than the large particles. This criteria was considered vital in choosing the ideal particle size as $125-250 \mathrm{~m} \mu$, furthermore smaller particles than this tend to clog the column during industrial applications. 


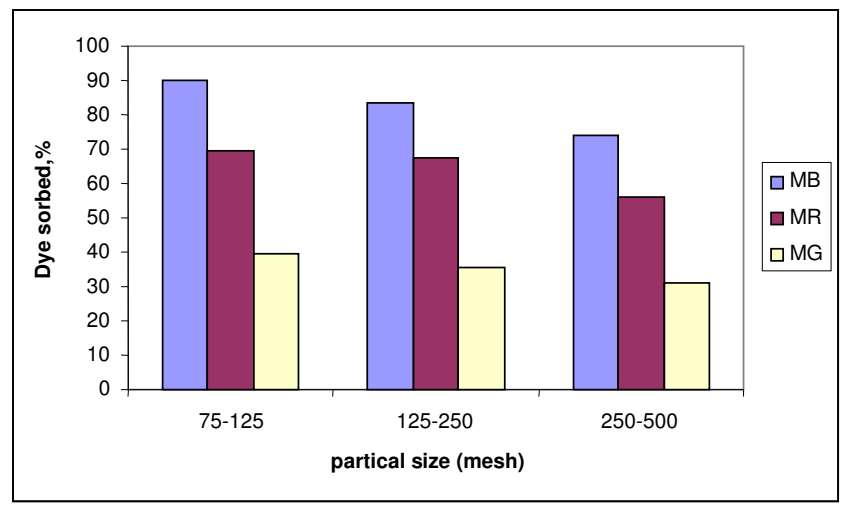

Figure 3. Effect of particle size on biosorption of MB, MR, and MG by granulized Annona squmosa seed (Sorbent dose: $200 \mathrm{mg} / 50 \mathrm{~mL}$; contact time: $3 \mathrm{~h}$; dye concentration: $100 \mathrm{mg} / \mathrm{L} ; \mathrm{pH}$ : 6.0 for $M B, 5$ for $M R \& M G)$.

\section{Effect of sorbent dose}

The sorption of the dyes on carbon was studied by varying the concentration of the granulized Annona squmosa seed biomass $(0.1-1.2 \mathrm{~g} / \mathrm{mL})$. The percentage of adsorption increased as the adsorbent concentration increased shown in Table 2. The increase in the percent removal of dyes with the increase in adsorbent dosage is due to the availability of larger surface area with more active functional groups at higher adsorbent dosages.

Table 2. Effect of adsorbent dosage on biosorption of dyes (dye concentration: $100 \mathrm{mg} / \mathrm{L}$; contact time: $3 \mathrm{~h} ; \mathrm{pH}$ : 6.0 for MB, 5 for MR \& MG).

\begin{tabular}{llll}
\hline \multirow{2}{*}{ Adsorbent concentration, mg/L } & \multicolumn{3}{c}{ Dye adsorbed, \% } \\
\cline { 2 - 4 } & MB & MR & MG \\
\hline 200 & 85.32 & 64.91 & 34.16 \\
400 & 88.99 & 78.36 & 37.88 \\
600 & 90.83 & 84.79 & 39.13 \\
800 & 92.66 & 90.64 & 40.37 \\
1000 & 97.86 & 91.22 & 40.99 \\
\hline
\end{tabular}

\section{Adsorption kinetics}

The kinetic data were treated with the following Lagergren's pseudo-first order rate equation:

$$
\log \left(\mathrm{q}_{\mathrm{e}}-\mathrm{q}_{\mathrm{t}}\right)=\lg \mathrm{q}_{\mathrm{e}}-\mathrm{k}_{\mathrm{ad}} \mathrm{t} / 2.303
$$

where, $\mathrm{q}_{\mathrm{e}}$ and $\mathrm{q}_{\mathrm{t}}(\mathrm{mg} / \mathrm{g}$ ) refer to the amount of dye adsorbed at equilibrium and time $\mathrm{t}(\mathrm{min})$, respectively and $\mathrm{k}_{\mathrm{ad}}$ is the rate constant. The rate constant $\mathrm{k}_{\mathrm{ad}}$ could be calculated from the slopes of the linear plots of $\log \left(\mathrm{q}_{\mathrm{e}}-\mathrm{q}_{\mathrm{t}}\right)$ versus $\mathrm{t}$. The Lagergren plots of dye biosorption are shown in Figure 4. The high values of correlation coefficients showed that the data confirmed well to the pseudo first order rate kinetic model.

$\mathrm{K}_{\mathrm{ad}}$ for MB was 0.01405

MR was 0.02349

MG was 0.03708 per minutes respectively.

\section{Spectrochemical characterization}

The FT-IR spectrum of the granulized Annona squmosa seed (Figure 5) showed that the most prominent peaks in the spectrum originate from $\mathrm{OH}$ vibrations, $\mathrm{CH}_{2}$ and $\mathrm{CH}_{3}$ 
asymmetric and symmetric stretching vibrations (2923-2852 $\left.\mathrm{cm}^{-1}\right)$. Peaks in region (700$669 \mathrm{~cm}^{-1}$ ) originate from the stretching mode of carbonyls mainly lactams. The peaks at (1155-1033 $\mathrm{cm}^{-1}$ ) region related to lignin. Therefore, it is possible that cellulose, hemicelluloses as well as lignin, having many $\mathrm{OH}$ groups in their structure, make the most absorbing layer.

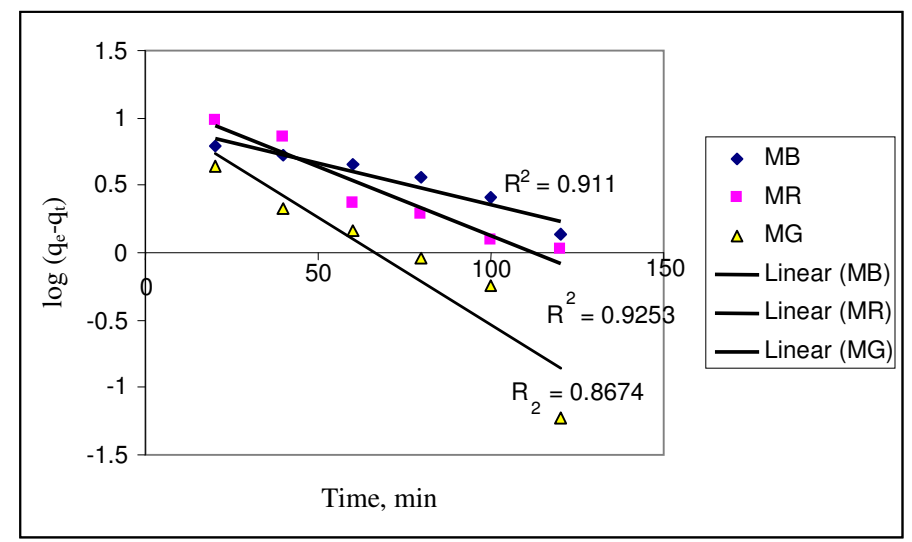

Figure 4. Lagergren plots for biosorption of MB, MR, and MG by granulized Annona squmosa seed (Sorbent dose: $200 \mathrm{mg} / 50 \mathrm{~mL}$; contact time: $3 \mathrm{~h}$; dye concentration: $100 \mathrm{mg} / \mathrm{L} ; \mathrm{pH}$ : 6.0 for $M B, 5$ for $M R \& M G)$.

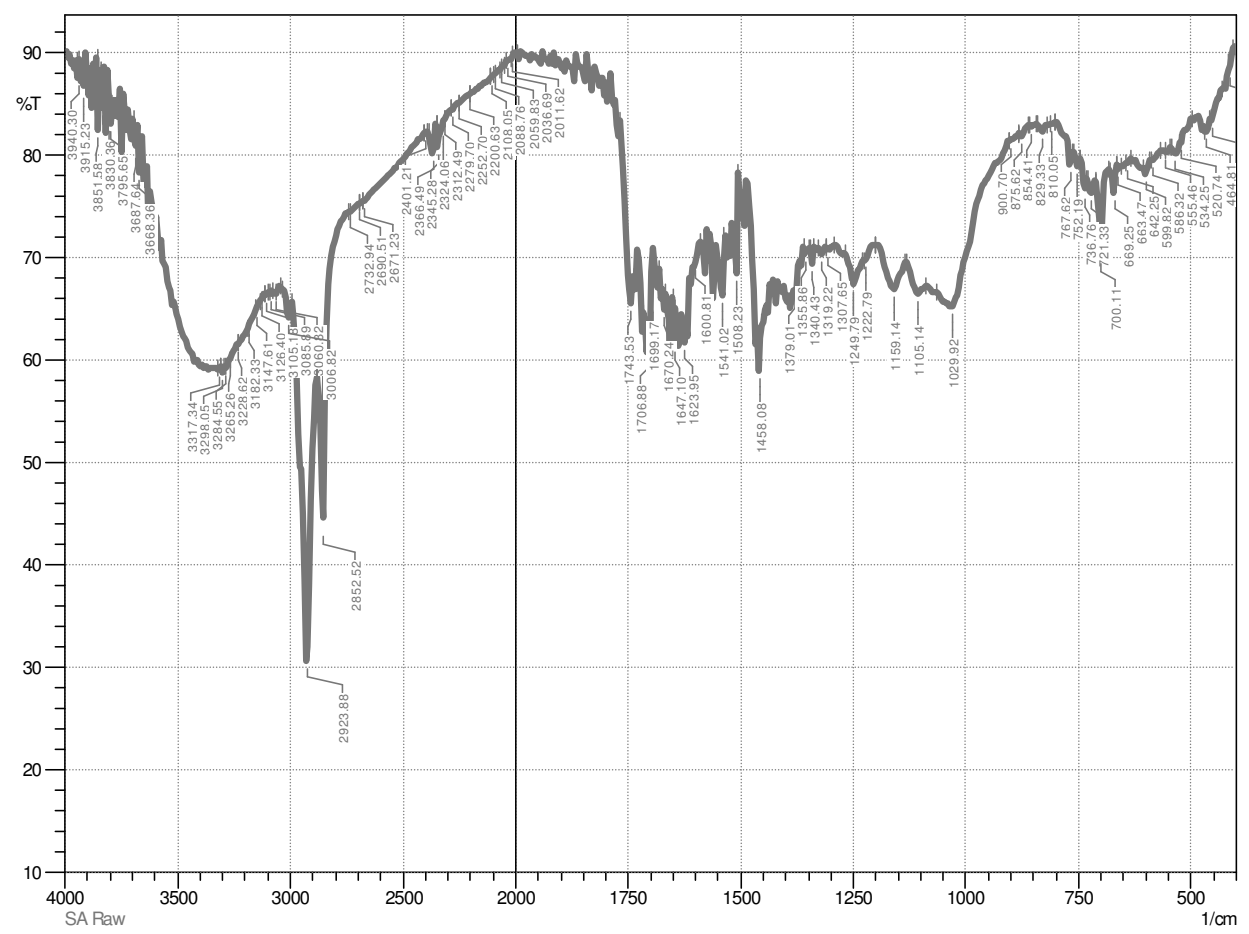

Figure 5. FTIR for the granulized Annona squmosa seed (before adsorption). 
This study confirmed that the biosorbent prepared from the granulized Annona squmosa seed biomass, a low cost agricultural waste, could effectively remove MB, MR and MG from an aqueous solution. The optimal $\mathrm{pH}$ for favorable sorption of dyes $\mathrm{pH}$ was 6 for $\mathrm{MB}$ and 5 for both MR and MG. The sorption equilibrium was reached in approximately $3 \mathrm{~h}$. The isothermal data fitted the Langmuir model in the case of MB sorption and the Freundlich model for all three dyes sorption. The biosorption processes followed the pseudo first order rate kinetics.

\section{References}

1. Sivaraj R, Namasivayam C and Kadirvelu K, Waste Manage., 2001, 21, 105-110.

2. Arami M, Yousefi Limaee N, Mahmoodi N M and Tabrizi N S, J Colloid Interface Sci. 2005, 288, 371-376.

3. Senthilkumaar S, Varadarajan P R, Porkodi K and Subbhuraam C V, J Colloid Interface Sci., 2005, 284, 78-82.

4. Brown P, Jefcoat I A, Parrish D, Gill S and Graham E, Adv Environ Res., 2000, 4, 19-29.

5. $\quad$ Singh K K, Talat M, Hasan S H, Biores. Technol., 2006, 97, 2124-2130.

6. Taty-Costodes V C, Fauduet H, Porte C and Delacroix A, J Hazard Mater., 2003, B 105,121-142.

7. Reddad Z, Gerente C, Andres Y and Cloirec P L, Environ Sci Technol., 2002, 36, 2067-2073.

8. Vijayaraghavan K, Palanivelu K and Velan M, Biores Technol., 2006, 97, 1411-1419.

9. Kweon D K, Choi J K, Kim E K and Lim S T, Carbohydr Polym., 2001, 46, 171-177.

10. Kumar U and Bandyopadhyay M, Biores Technol., 2006, 97, 104-109.

11. Ghimire K N, Inoue K, Miyajima T, Yoshizuka K and Shoji T, Chitin and Chitosan Research, 2001, 7(2),61-68.

12. Dhakal R P, Ghimire K N, Inoue K, Yano M and Makino K, J Sep Pur Technol., 2005, 42, 219-225.

13. Vasanth Kumar K, Dyes and Pigments, 2007, 74, 595-597.

14. Renmin Gong, Xiaoping Zhang, Huijun Liu, Yingzhi Sun and Birong Liu, Biores Technol., 2007, 98,1319-1323.

15. Husseien M, Amer A A, Azza EI- Maghraby, Nahla A and Taha, J Appl Sci Res., 2007, 3(11), 1352-1358.

16. Maheswari P, Venilamani N, Madhavakrishnan S, Syed Shabudeen P S, Venckatesh, R, Pattabhi S, E J Chem., 2008, 5(2), 233-242. 


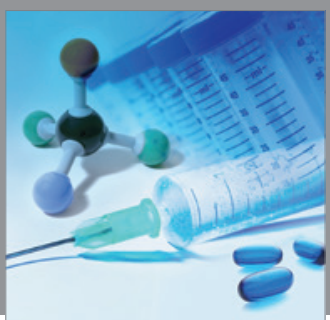

International Journal of

Medicinal Chemistry

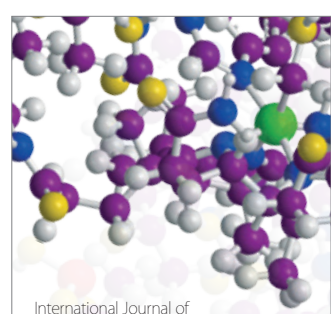

Carbohydrate Chemistry

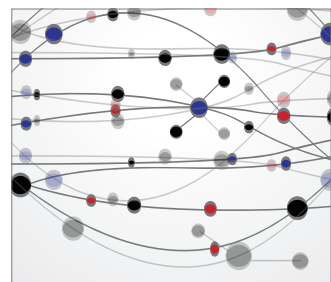

The Scientific World Journal
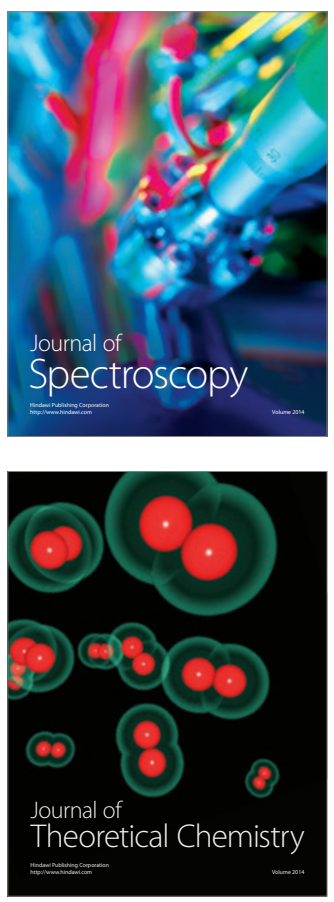
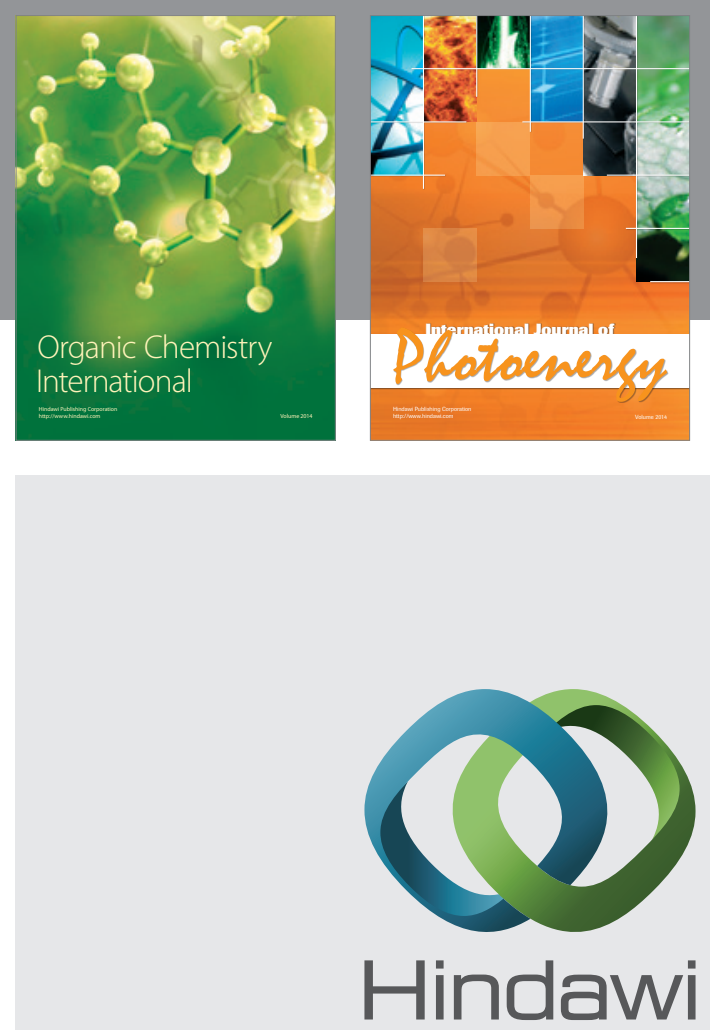

Submit your manuscripts at

http://www.hindawi.com
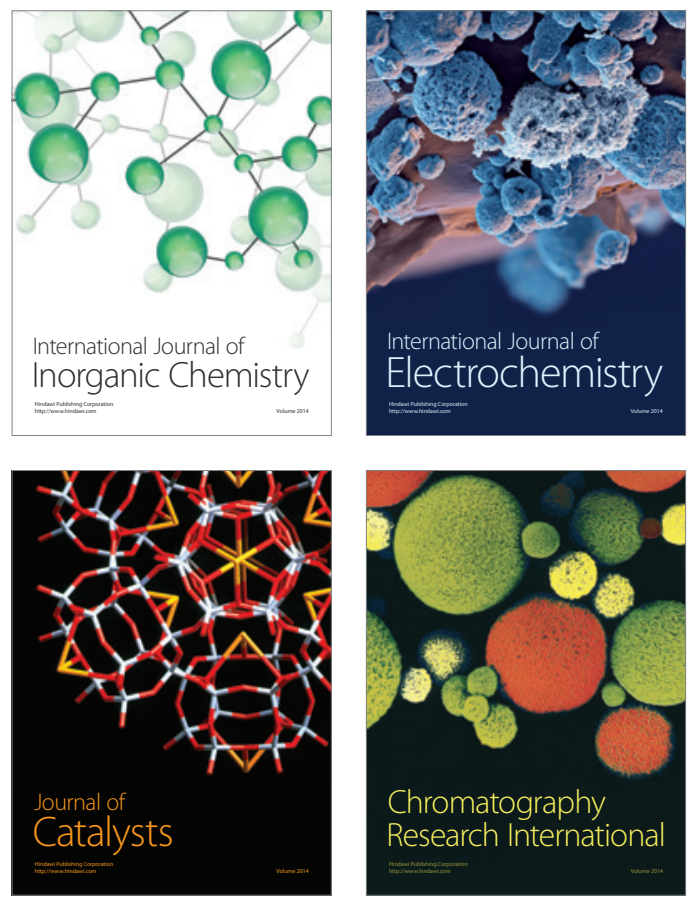
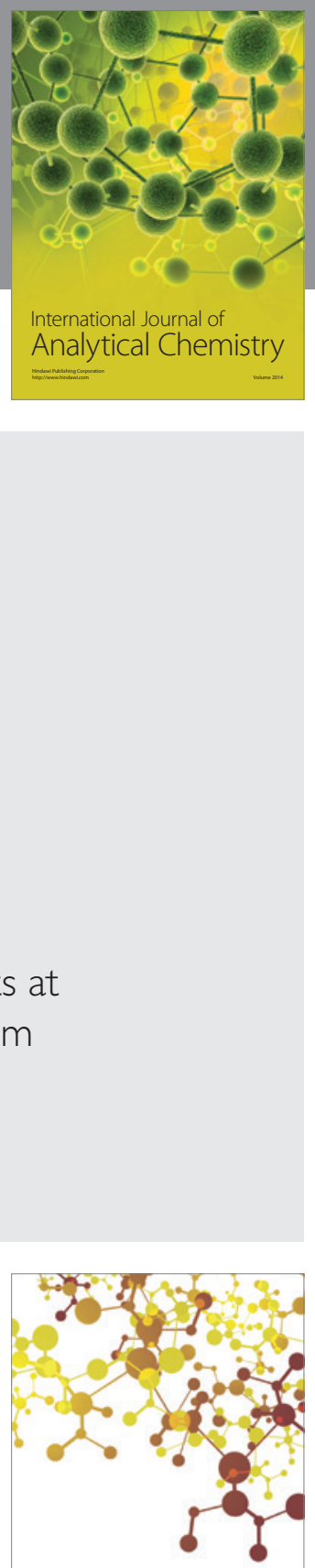

Journal of

Applied Chemistry
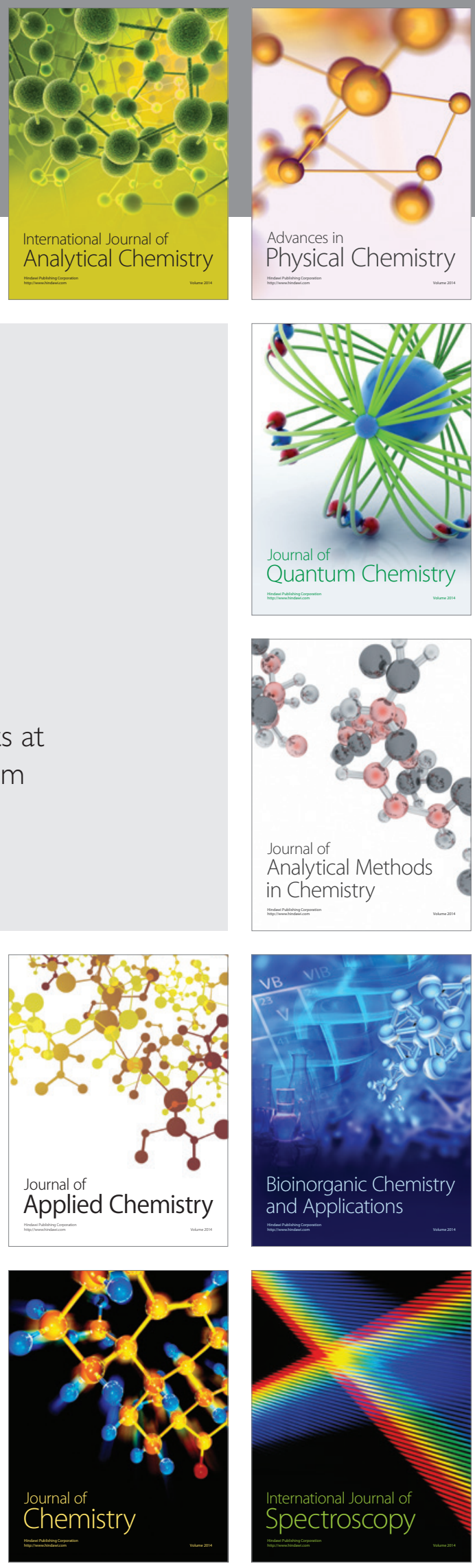